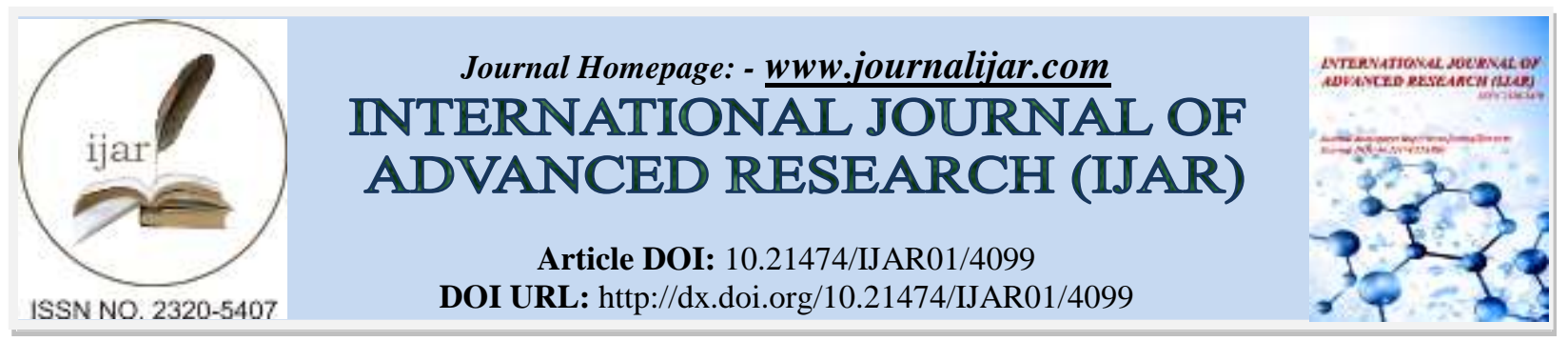

RESEARCH ARTICLE

\title{
TO STUDY THE OUTCOME OF TREATMENT IN INFRARENAL MULTILEVEL OCCLUSIVE DISEASE.
}

Dr. Lakshmidharan.M ${ }^{1}$, Dr. S. R. Subrammaniyan ${ }^{2}$, Dr.Thulasikumar.G ${ }^{1}$, Dr. Sritharan. $\mathbf{N}^{3}$ and Dr. K. Jeyachander ${ }^{1}$.

1. Department of Vascular Surgery, Stanley Medical College, Chennai.

2. Department of Vascular Surgery, Saveetha Medical College, Chennai.

3. Institute of Vascular Surgery, Madras Medical College, Chennai.

\section{Manuscript Info}

(.........................

Manuscript History

Received: 08 March 2017

Final Accepted: 07 April 2017

Published: May 2017

Key words:-

Multilevel occlusive disease, critical

limb ischemia.

\section{Abstract}

Objective: The purpose of this study was to compare between the proximal and total revascularization in patients with infrarenal multilevel occlusive disease.

Materials and Methods: This is a study Prospective and comparative study analysis of proximal and total revascularization in infrarenal multilevel occlusive disease done in patients with critical limb ischemia attending vascular surgery department of Govt. Stanley Medical College and Hospital, Chennai during study period between October 2012 to December 2014.

Results: Totally 25 patients were enrolled in the study with patients having good profunda patency subjected to proximal bypass, those with poor profunda patency and two patients with forefoot gangrene undergone sequential bypass. Thus by above criteria ten underwent proximal bypass and 15 had sequential bypass. There was significant improvement in ulcer healing, pain reduction and $\mathrm{ABI}$ improvement in sequential bypass group than that of proximal bypass.

Conclusion: This study strongly reveals that single-stage multisegment reconstruction for multilevel arterial occlusive disease is a safe and effective method of treating critical limb ischemia.

Copy Right, IJAR, 2016,. All rights reserved.

\section{Introduction:-}

Clinical manifestation of atherosclerosis involving the abdominal aorta and iliac arteries is one of the most common therapeutic challenges encountered by vascular surgeons. Treatment of chronic critical limb ischemia still remains one of the most serious problems of vascular surgery. Most often, chronic critical limb ischemia is caused by multisegmental disease of arterial tree, involving both the aorto-femoral and infrainguinal vessels. ${ }^{8,9}$ The optimal management of patients with multilevel occlusive disease is often difficult to determine. The question frequently arises whether or under what circumstances concomitant versus staged outflow procedures should be performed in association with an inflow operation. ${ }^{1,2,3,9}$

The optimal management of patients with multilevel occlusive disease is often difficult to determine. The question frequently arises whether or under what circumstances concomitant versus staged outflow procedures should be 
performed in association with an inflow operation. Of relevance, the impact of synchronous Superficial Femoral Artery disease on the results of Aorto-iliac revascularization remains undefined in the current literature;

some reports have indicated similar patency rates between patients with and without Superficial Femoral Artery occlusion, whereas others have reported lower long-term patency rates in this setting. ${ }^{4,5}$

If an atretic or prohibitively diseased profunda is present in addition to a severely diseased Superficial Femoral Artery, infrainguinal bypass grafting is likely to be necessary to ensure sufficient outflow for graft patency and perfusion of the foot. No single criterion mandates a combined procedure; however, the severity of distal ischemia is probably the most important factor to be considered. ${ }^{6,7}$

If significant tissue loss is present, concurrent inflow and outflow procedures are probably warranted if limb salvage is to be achieved. In deciding whether a staged approach is appropriate, the patient's ability to tolerate a prolonged operative procedure must be weighed against the potential risk of wound and graft infection resulting from redissection in the groin and the risk of progressive tissue loss during the initial recuperative period. When it is performed with several teams operating simultaneously, concurrent inflow and outflow revascularization can be completed in a timely and safe manner. Indeed, several reports found no significant differences in preoperative mortality or morbidity in patients undergoing multilevel reconstruction and those having the major inflow procedure alone.

Multilevel arterial occlusive disease is often the main cause of critical ischemia of the lower limb. The aim of this study was to compare the results after simultaneous and two-stage surgery in select patients for sequential aortofemoropopliteal/ distal reconstruction.

Our data demonstrate that single-stage multisegment reconstruction for multilevel arterial occlusive disease is a safe and effective method of treating critical limb ischemia., ${ }^{9,10}$

\section{Materials and Methods:-}

Study Design: This study is a Prospective and comparative study analysis of proximal and total revascularisation in infrarenal mutilevel occlusive disease

Period of study: October 2012 to December 2014.

Setting: All these patients with critical limb ischemia attending the Vascular Surgery OPD of Govt. Stanley Medical College and Hospital, Chennai were enrolled for study. All these patients were admitted and evaluated with proper clinical history, thorough clinical examination, ABI monitoring preoperatively and postoperatively, a follow up period of minimum three months and quality of life improvement after surgery. Based on inclusion and exclusion criteria patients were selected and treated accordingly.

\section{Inclusion Criteria:-}

1. All vascular patients with multilevel occlusive disease below the infrarenal aorta.

2. All patients with critical limb ischemia

\section{Exclusion Criteria:-}

1. Vascular trauma

2. Single level occlusive disease

3. Aortic aneurysm

4. Subacute bacterial endocarditis

5. Patients on treatment for malignancy

6. Combined interventional and surgical procedure.

7. Extranatomical bypasses 


\section{Results and Discussion:}

Totally 25 patients were enrolled in the study, with patients having good profunda patency subjected to proximal bypass and those with poor profunda patency undergone sequential bypass. Thus by above criteria ten underwent proximal bypass and 15 had sequential bypass.

Table 1:- Characterisitcs Features.

\begin{tabular}{|l|l|l|}
\hline S.NO. & CHARACTERISITCS FEATURES & $\begin{array}{l}\text { NUMBER/ } \\
\text { PERCENTAGE }\end{array}$ \\
\hline 1. & ETIOLOGY: & \\
& BEURGER'S DISEASE & $7(28 \%)$ \\
& ATHEROSCLEROSIS & $18(72 \%)$ \\
\hline 2 & BYPASS TYPE: & $10(40 \%)$ \\
& PROXIMAL $:$ & $15(60 \%)$ \\
\hline 3 & SEQUENTIAL: & $18(73 \%)$ \\
& COMORDIBITIES: & $3(13 \%)$ \\
& SMOKING & $4(14 \%)$ \\
\hline 4 & HYPERTENSION & $12(48 \%)$ \\
& DIABETES & $13(52 \%)$ \\
\hline & PROFUNDA PATENCY: & \\
\hline
\end{tabular}

Table 2:- Proximal Bypass Vs Sequential Bypass

\begin{tabular}{|c|c|c|c|}
\hline S.NO & CHARACTERISTICS & $\begin{array}{l}\text { PROXIMAL } \\
\text { BYPASS }(\mathrm{N}=10)\end{array}$ & $\begin{array}{l}\text { SEQUENTIAL } \\
\text { BYPASS } \\
(\mathrm{N}=15)\end{array}$ \\
\hline 1 & $\begin{array}{l}\text { AGE : } \\
40-50 \text { YEARS } \\
51-60 \text { YEARS } \\
61-70 \text { YEARS }\end{array}$ & $\begin{array}{l}4 \\
2 \\
4\end{array}$ & $\begin{array}{l}5 \\
4 \\
6\end{array}$ \\
\hline 2 & $\begin{array}{l}\text { GENDER: } \\
\text { MALE } \\
\text { FEMALE }\end{array}$ & $\begin{array}{l}10 \\
0\end{array}$ & $\begin{array}{l}15 \\
0\end{array}$ \\
\hline 3 & PALPABLE PULSE & 0 & $13(86.67 \%)$ \\
\hline 4 & MEAN ABI IMPROVEMENT & 0.5 & 1 \\
\hline 5 & $\begin{array}{l}\text { AVERAGE MONTHS FOR } \\
\text { ULCER HEALING }\end{array}$ & 5 MONTHS & $1 \mathrm{MONTHS}$ \\
\hline 6 & CLAUDICATION PAIN IMPROVEMENT & $3(30 \%)$ & $13(86.67 \%)$ \\
\hline 7 & $\begin{array}{l}\text { COMPLICATIONS: } \\
\text { PSEUDOANEURYSM } \\
\text { GRAFT THROMBOSIS }\end{array}$ & $\begin{array}{l}2(20 \%) \\
1(10 \%)\end{array}$ & $\begin{array}{l}0 \\
2(13 \%)\end{array}$ \\
\hline
\end{tabular}


Figure 1:- Ct Angiograms Showing Multilevel Occlsuions

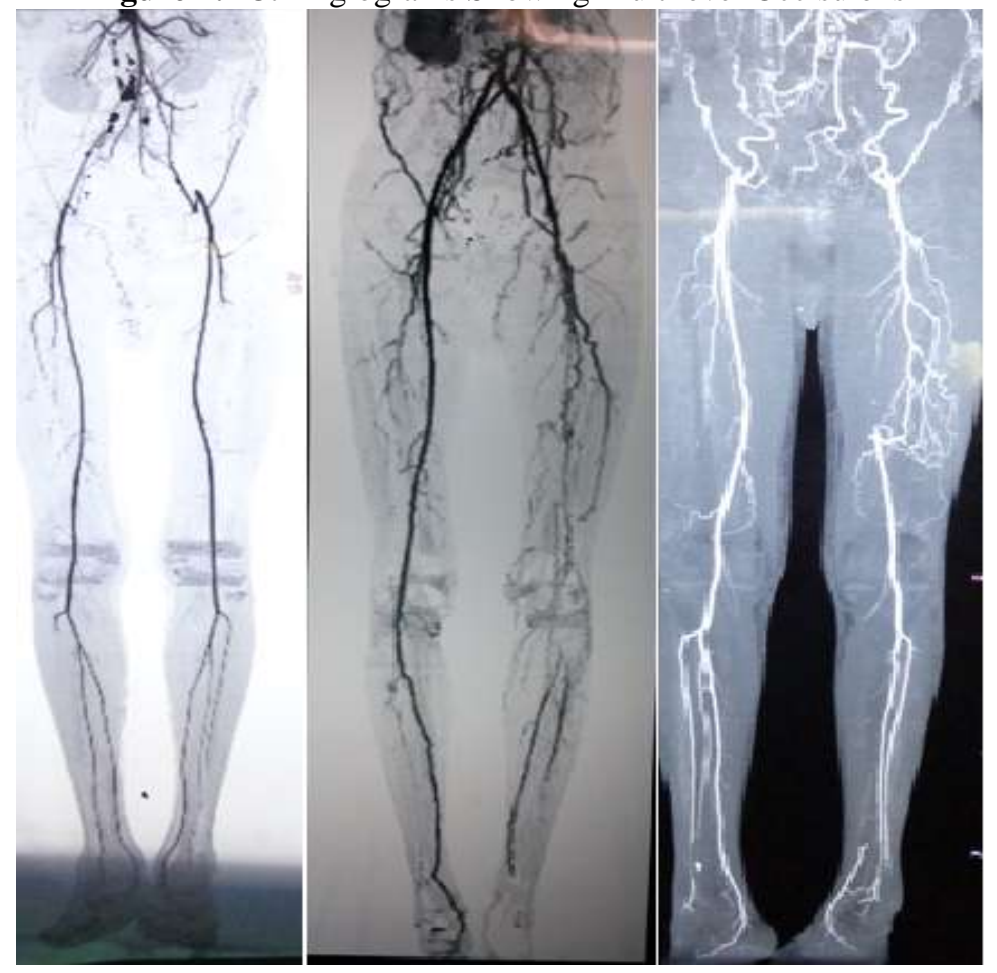

Figure 2:- a) proximal aorta to ptfe graft bypass

b) sequential graft to gaft bypass

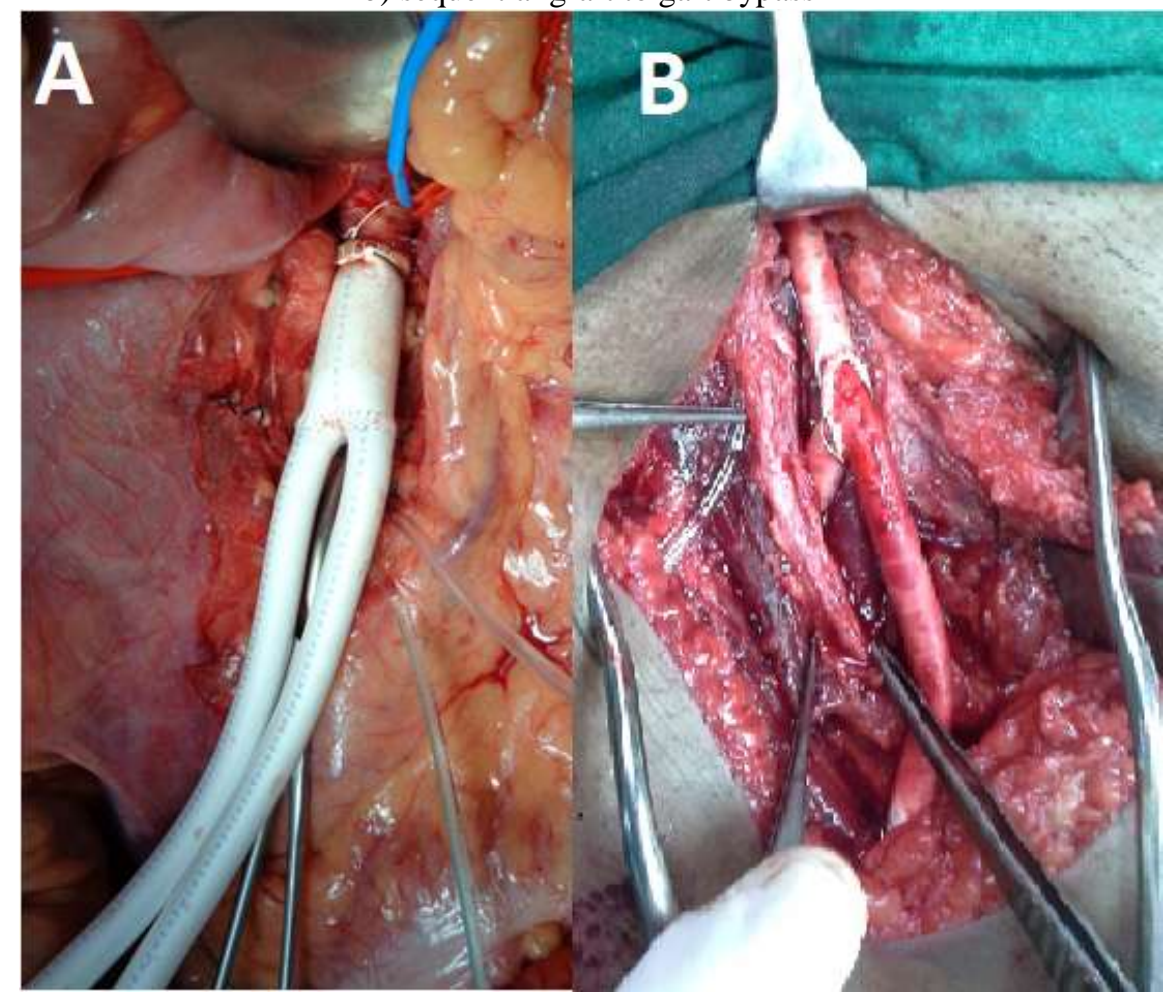


Thus from above table features such as ulcer healing, improvement in claudication pain, palpable pulse and ABI improvement were statistically better in sequential bypass group than proximal bypass group. Graft patency was nearly similar $10 \%$ vs. $13 \%$ without any statistical significance. One patient in sequential bypass group underwent major amputation (below knee amputation) and there were no perioperative mortality in both groups.

\section{Conclusion:-}

All patients presented with critical limb ischemia. Marked ABI improvement in pateints with sequential bypass category. The ulcer healing rate is very fast in patents who underwent sequential bypass. Even though the ulcer heals in patients who underwent proximal lesion correction they have claudication. This study strongly reveals that sequential bypass gives the best result in critical limb ischaemia. Hence single-stage multisegment reconstruction for multilevel arterial occlusive disease is a safe and effective method of treating critical limb ischemia.

\section{References:-}

1. Evaluation of claudication. Vascular Diagnosis, Philadelphia: Elsevier, Inc.; 2004.

2. Gahtan V: The noninvasive laboratory. Surg Clin North Am 1998; 78:507-518.

3. Heijenbrok-Kal MH, Kock MC, Hunink MG: Lower extremity arterial disease: multidetector CT angiography - meta-analysis. Radiology 2007; 245:433-439.

4. Kreitner KF, Kalden P, Neufang A, et al: Diabetes and peripheral arterial occlusive disease: prospective comparison of contrast-enhanced three-dimensional MR angiography with conventional digital subtraction angiography. Am J Radiol 2000;174:171-179.

5. Norgren L. Hiatt WR, Dormandy JA. El at. Inter-Society Consensus for the Management of the Peripheral Arterial Disease (TASC II). J Vasc Surg 2007, 45(SupplS) S5-S67.

6. Ota H, Takase K, Igarashi K, et al: MDCT compared with digital subtraction angiography for assessment of lower extremity arterial occlusive disease: importance of reviewing cross-sectional images. Am J Roentgenol 2004; 182:201- 209.

7. Ouwendijk R, Kock MC, van Dijk LC, et al: Vessel wall calcifications at multi-dectector row CT angiography in patients with peripheral arterial disease: effect on clinical utility and clinical predictors. Radiology 2006; 241:603-608.

8. Platt JF: Doppler ultrasound of the kidney. Semin Ultrasound CT MR 1997; 18:22.

9. Rutherford's Vascular Surgery, Jack L. Cronenwett, K. Wayne Johnston, Eighth Edition, Volume 2, section 18 :pg.1660-1800.

10. Soares GM, Murphy TP, Singha MS, et al: Renal artery duplex ultrasonography as a screening and surveillance tool to detect renal artery stenosis: a comparison with current reference standard imaging. J Ultrasound Med 2006; 25:293. 